\title{
Studies on the 'Osmophilic' Yeast Saccharomyces rouxii and an Obligate Osmophilic Mutant
}

\author{
By T. Y. KOH \\ Sub-department of Chemical Microbiology, Department of Biochemistry, \\ University of Cambridge, Cambridge $C B 2$ I $Q W$
}

(Received I9 April I974; revised I I October 1974)

SUMMARY

An obligate osmophilic mutant (strain BI/4) of Saccharomyces rouxii has been isolated that fails to grow at osmotic pressures corresponding to $20 \%(\mathrm{w} / \mathrm{v})$ sucrose or less. In $30 \%$ sucrose the yeast is filamentous and grows slowly. In $40 \%$ sucrose it is mainly filamentous and has over twice the normal diameter. In $60 \%$ sucrose it grows in the yeast form with a growth rate twice that of the culture in $40 \%$ sucrose. This mutant is lysed by a sudden drop in the osmotic pressure of the environment. Cell envelopes of the parent strain contained glucose and mannose in the ratio $\mathrm{I} \cdot 2: \mathrm{I}$ and contained $3.8 \%(\mathrm{w} / \mathrm{v})$ hexosamine, whereas the envelopes of the mutant contained $0.8 \%$ hexosamine. Cell envelopes of the mutant grown in $40 \%$ sucrose contained glucose and mannose in the ratio $\mathrm{I} \cdot 9: \mathrm{I}$, whereas for envelopes of the yeast grown in $60 \%$ sucrose the ratio was $I \cdot 2: I$. Neutral lipids from whole cells and those from the envelopes of the mutant strain generally contained more unsaturated fatty acids than the corresponding fractions from the parent strain.

\section{INTRODUCTION}

Obligate osmophilic mutants of the yeast Saccharomyces rouxii have been isolated as reported in an accompanying paper (Koh, 1975). These mutants require an environment of high sugar or salt concentration for growth. The changes in the growth characteristics, morphology and chemistry of the mutant BI/4 and its parent strain, as functions of the concentration of sugar present during growth, were studied. Cell envelopes were isolated and their chemical composition determined.

\section{METHODS}

Materials. All reagents used were of Analar grade, and organic solvents used for isolation of lipids were redistilled and stored in dark bottles in the dark. All percentages are weight per volume unless otherwise stated.

Organisms, growth media and conditions of growth. A strain of Saccharomyces rouxii Boutroux (sa 24), isolated from Mauritius sugar by Dr M. P. Scarr (Scarr \& Rose, 1966), and the mutant strain BI/4 derived therefrom (Koh, 1975) were used in this work. Stock cultures were maintained on agar slopes (Davies, 1964) containing $0.2 \%$ yeast extract (Difco) supplemented with $10 \%(\mathrm{w} / \mathrm{v})$ glucose and $40 \%(\mathrm{w} / \mathrm{v})$ sucrose. The cultures were stored at $4{ }^{\circ} \mathrm{C}$ and transferred to fresh slopes every six months. For use in experiments, organisms were grown at $30{ }^{\circ} \mathrm{C}$ in a defined medium (Davies, 1964) normally supplemented with $2 \%$ glucose as sole carbon source (D medium) with or without sucrose at the concentrations stated in the text.

A small loopful of yeast (approx. $10^{8}$ cells) from a slope was inoculated into $100 \mathrm{ml}$ of 
defined medium in a $250 \mathrm{ml}$ conical flask. The culture was shaken at $\mathrm{I} 20$ oscillations/min and allowed to grow to early stationary phase. For $S$. rouxii this took $48 \mathrm{~h}$ and for mutant BI $/ 4$ approximately $\mathrm{I} 00 \mathrm{~h}$. These organisms were then subcultured into I 1 batches of media contained in 21 conical flasks, to give cell densities of approximately $7 \times 10^{-3} \mathrm{mg} \mathrm{dry} \mathrm{wt} / \mathrm{ml}$, and the cultures incubated in an orbital shaker at 200 oscillations/min until the cultures were in mid-exponential phase of growth $(0.3$ to $1 \cdot 0 \mathrm{mg} / \mathrm{ml})$. This required $15 \mathrm{~h}$ for the parent yeast and 40 to $60 \mathrm{~h}$ for strain $\mathrm{BI} / 4$.

Cell concentrations were measured by diluting samples with isotonic $\mathrm{KCl}$ and measuring turbidity with a Spekker absorptiometer (Hilger). Growth characteristics were followed by measuring turbidity, which was related to dry weight by calibration curves determined as described below.

Harvesting and preparation of cell suspensions. Cells grown in high sucrose concentrations were harvested by diluting the cultures with an equal volume of cold isotonic $\mathrm{KCl}$ to reduce the viscosity and centrifuging at $4{ }^{\circ} \mathrm{C}$ for Io min at $22000 \mathrm{~g}$. The pellets were washed twice by suspending in isotonic $\mathrm{KCl}$ and centrifuging for 5 min at $\mathrm{I} 2000 \mathrm{~g}$. The cells thus obtained were resuspended in an appropriate buffer at the required concentration.

Preparation of lyophilized cells for chemical studies. The $\mathrm{KCl}$-washed yeast was further washed with $100 \mathrm{ml}$ cold distilled water, resuspended in water, frozen and lyophilized. The water wash removed not more than $2 \%$ of the total cell mass as estimated by assay of protein, carbohydrate, nucleic acids and inorganic phosphate. Salt-washed preparations of the mutant yeast ( 100 to $200 \mathrm{mg} / \mathrm{ml}$ ) were filtered, under suction, through glass-fibre filters mounted on sintered-glass filters. Surplus $\mathrm{KCl}$ was washed away quickly with 2 to $5 \mathrm{ml}$ cold distilled water. The cells were then lyophilized. This procedure was adopted to minimize leakage of intracellular material by sudden changes of osmotic pressure, and it was found that no more than $2 \%$ of the cell material was present in the filtrate in the form of protein, carbohydrate and nucleic acids.

Relationship between dry weight and turbidity. Since the mutant yeast cells were lysed by a sudden decrease in osmotic pressure, a procedure for estimating their dry weight was devised such that a minimum of intracellular material was lost. The yeast was diluted with an equal volume of isotonic $\mathrm{KCl}$ and washed twice by centrifugation at $30{ }^{\circ} \mathrm{C}$ with isotonic potassium phosphate buffer at $\mathrm{pH} 7$. Thus the concentration of the solution was $0.4 \mathrm{M}$ for yeast grown in the presence of $40 \%$ sucrose and $0.6 \mathrm{M}$ for yeast grown in $60 \%$ sucrose. No crystallization of potassium phosphate occurred at $30{ }^{\circ} \mathrm{C}$. Pelleted yeast was resuspended in 3 to $5 \mathrm{ml}$ of the same buffer. Duplicate $\mathrm{I} \mathrm{ml}$ samples were transferred to tared crucibles, dried at $105^{\circ} \mathrm{C}$ for $48 \mathrm{~h}$, cooled in vacuo, and weighed. The mass due to buffer constituents was determined by measuring the phosphate contents of the yeast suspensions after dilution with isotonic $\mathrm{KCl}$ and removal of cells by centrifugation, and the mass due to the yeast obtained by subtracting this from the total weight. To determine the relationship between cell mass and turbidity, yeast suspensions of known dry wt/ml were diluted either with $\mathrm{KCl}$ isotonic to the growth medium or with appropriate mixtures of $\mathrm{KCl}$ and sucrose.

Osmotic fragility. The yeast was grown in D medium plus sucrose and harvested as described above. Duplicate samples (Io to $50 \mathrm{mg}$ dry weight) were centrifuged at $900 \mathrm{~g}$ for Io min. One sample was resuspended in $\mathrm{KCl}$ solution isotonic to the growth medium and the other sample was suspended in $3 \mathrm{ml}$ distilled water. The samples were left at $20{ }^{\circ} \mathrm{C}$ for Io min and the yeast harvested by centrifugation. The supernatant solutions were recentrifuged to remove any unpelleted yeast. This procedure was repeated twice. The yeast pellets from a given sample were combined, resuspended in $3 \mathrm{ml}$ distilled water, heated at $100{ }^{\circ} \mathrm{C}$ for 10 min and undissolved material removed by centrifugation. The cold and hot extracts 
were diluted appropriately and their $E_{260}$ measured. The relative amount of u.v.-absorbing material released in the cold was taken as a measure of osmotic fragility. Protein was assayed (Lowry et al. 1951) without prior trichloroacetic acid precipitation.

Isolation of yeast envelopes. The yeast was suspended (50 to $150 \mathrm{mg}$ dry $w \mathrm{t} / \mathrm{ml}$ ) in $\mathrm{KCl}$ solution isotonic to the growth medium and containing Io mM-tris- $\mathrm{HCl}$ buffer at $\mathrm{pH} 7 \cdot 2$. The suspension ( 5 to $10 \mathrm{ml}$ ) was mixed with an equal volume of No. I 2 Ballotini beads in a $25 \mathrm{ml}$ masticator (MSE 773 I3) and blended at $9000 \mathrm{rev}$./ $\mathrm{min}$ in an ice/salt mixture for $15 \mathrm{~min}$ by means of an MSE microhomogenizer. By this procedure, over $98 \%$ cell breakage was usually obtained. Otherwise, the suspensions were centrifuged and the pellets subjected to a further 5 min homogenization with Ballotini beads, after resuspension in buffered isotonic $\mathrm{KCl}$.

Yeast envelopes were separated by the method of Nurminen, Oura \& Suomalainen ( I 970), involving centrifugation at $600 \mathrm{~g}$. The product was either lyophilized or used directly for lipid extraction and chemical analysis. The supernatant solutions, after removal of the envelopes, were centrifuged at $10000 \mathrm{~g}$ for Io $\mathrm{min}$. The pellets were suspended in small volumes of $10 \mathrm{mM}$-tris- $\mathrm{HCl} \mathrm{pH}_{7 \cdot 2}$ for the assay of succinic dehydrogenase (SDH).

Purity of the yeast envelope preparations was based on the following criteria: (i) appearance under phase-contrast microscope and on negative staining; (ii) absence of SDH activity - an indication of freedom from mitochondrial contamination; (iii) constancy in chemical composition - an indication of homogeneity.

Succinic dehydrogenase assay. SDH was assayed by the method of Duncan \& Mackler (1966), involving phenazine methosulphate-dependent reduction of dichlorophenyl indophenol (DCPIP).

\section{Chemical composition}

For estimation of protein and carbohydrate, cells and cell envelopes (approx. $5 \mathrm{mg}$ ) were digested with $\mathrm{N}-\mathrm{NaOH}$ at $70^{\circ} \mathrm{C}$ for 10 min to solubilize proteins and disperse polysaccharides. For nucleic acid estimation samples were extracted three times with $0.5 \mathrm{~N}-$ perchloric acid at $70{ }^{\circ} \mathrm{C}$ for $30 \mathrm{~min}$ and the extracts pooled.

Total carbohydrate was estimated by procedure 3 of Devor (1950). Standard curves were prepared by using glucose and mannose (o to I00 $\mu \mathrm{g}$ ). $E_{570}$ for glucose was I 32 times the mannose equivalent. For determination of the composition of whole yeasts, the relative amounts of these sugars were assumed to be $\mathrm{I}: \mathrm{I}$, and for yeast envelopes the mannose: glucose ratios were determined by gas-liquid chromatography and the appropriate mixture of mannose and glucose used as the standard for carbohydrate estimation.

Protein was estimated by the method of Lowry et al. (I95I) on $\mathrm{NaOH}$ extracts.

$R N A$ was estimated from the $E_{260}$ of $\mathrm{I} \mathrm{N}-\mathrm{NaOH}$ or $0.5 \mathrm{~N}$-perchloric acid extracts. Absorption due to protein was corrected for by assuming that $\mathrm{I} \mu \mathrm{g}$ protein $/ \mathrm{ml}$ increases $E_{260}$ by 0.00 I unit. A standard curve for yeast RNA hydrolysed in $0.5 \mathrm{~N}$-perchloric acid showed that $E_{260}$ was I.0 at $38 \cdot 7 \mu \mathrm{g} \mathrm{RNA} / \mathrm{ml}$.

$D N A$ in perchloric acid extracts was estimated by the Giles \& Meyer (I965) modification of the Burton (1956) method. Standard curves were made by using calf-thymus DNA.

Total hexosamine. Samples of lyophilized yeast envelope ( 2 to $4 \mathrm{mg}$ ) were digested and samples were withdrawn and assayed by the Morgan-Elson reaction as described by Ghuysen, Tipper \& Strominger (1966). A calibration curve was obtained by subjecting 0 to $500 \mathrm{nmol}$ of glucosamine to the same hydrolysis treatment in the presence of $2 \mathrm{mg}$ glucose. In the absence of glucose, glucosamine was destroyed by the hydrolysis treatment and the development of chromogen was much reduced. The presence of glucose prevented this, but 
the absorbance of the blank was increased to about 0.15 units, which was low compared with the experimental values obtained. Inclusion of glucose in the standards corrects for interference due to the carbohydrate content of the samples. Some yeast envelopes were assayed in the presence of added glucose and, after correction for interference of carbohydrates, gave similar results to those obtained in the absence of added glucose.

Neutral sugar. Cell envelopes (approx. $5 \mathrm{mg}$ ) were hydrolysed by the method of Saeman et al. (1954). The neutralized deionized product was dried in vacuo at $45^{\circ} \mathrm{C}$ and dissolved in I $\mathrm{ml}$ of pyridine dried over molecular sieve type $4 \mathrm{~A}$. Isomeric forms of sugars were equilibrated by heating at $100{ }^{\circ} \mathrm{C}$ for $30 \mathrm{~min}$. They were then trimethylsilylated by the method of Sweeley et al. (1963). The dried products were dissolved in $2 \mathrm{ml}$ petroleum spirit (b.p. 60 to $80{ }^{\circ} \mathrm{C}$ ). Samples ( $\mathrm{I}$ to $5 \mu \mathrm{l}$ ) were analysed by gas-liquid chromatography on a column of $10 \%$ polyethylene glycol adipate (Pye) on 100 to 120 mesh celite (BDH), by means of a Pye 104 argon chromatograph with dual flame ionization detectors. The argon and hydrogen flow rate was about $40, \mathrm{ml} / \mathrm{min}$ and that of air was about $600 \mathrm{ml} / \mathrm{min}$. The temperature was programmed for the range 90 to $190{ }^{\circ} \mathrm{C}$ at $4{ }^{\circ} \mathrm{C} / \mathrm{min}$. Trimethyl silylated inositol was used as a marker for identification of peaks. The relative amount of each sugar was estimated from the peak areas.

Lipids. (i) Extraction, purification and total lipid estimation. Lyophilized yeast or yeast envelopes (50 to $100 \mathrm{mg}$ ) were resuspended in distilled water ( $\mathrm{I}$ to $20 \mathrm{ml}$ ), dispersed by brief sonication, and lipid extracted by the method of Suomalainen \& Nurminen (1970). Extracts were then purified by the method of Wells \& Dittmer (1963). The eluates were dried in vacuo and weighed.

(ii) Fractionation. This was done by the column chromatographic method described by Rouser, Kritchevsky \& Yamamoto (1967) for separation of lipids into neutral, glyco- and phospholipids. Silicic acid (Mallinckrodt, I00 mesh) was mixed with celite (coarse grade from $\mathrm{BDH})$ in a ratio of $\mathrm{I}: \mathrm{I}(\mathrm{w} / \mathrm{w})$ to facilitate elution by increasing the flow rate of solvents. Each eluate was dried under vacuum at $40{ }^{\circ} \mathrm{C}$ and the content of each class of lipid was estimated as described for total lipids. Each fraction was redissolved in $\mathrm{CHCl}_{3}$ and stored under $\mathrm{N}_{2}$ at $-20{ }^{\circ} \mathrm{C}$ until used for further analyses.

(iii) Thin-layer chromatography. All thin-layer plates were coated with Kieselgel $G$ (Merck) at a thickness of $0.25 \mathrm{~mm}$. Neutral lipids were chromatographed by using a solvent system of petroleum ether (b.p. $40^{\circ}$ to $60^{\circ} \mathrm{C}$ )-diethyl ether-formic acid (85: I5: I, by vol.), phospholipids in $\mathrm{CHCl}_{3}-\mathrm{MeOH}-\mathrm{H}_{2} \mathrm{O}\left(65: 25: 4\right.$, by vol.) and glycolipids in $\mathrm{CHCl}_{3}-\mathrm{MeOH}-$ acetic acid.(100:25:8, by vol.). Amino groups (on phosphatidyl ethanolamine) were detected by spraying the plates with $\mathrm{I} \%$ ninhydrin in $96 \%$ ethanol, phospholipids by the molybdate stain of Dittmer \& Lester (1964), and glycolipids by a diphenylamine spray containing $20 \mathrm{ml}$ alcoholic $10 \%$ diphenylamine, $100 \mathrm{ml}$ conc. $\mathrm{HCl}$ and $80 \mathrm{ml}$ acetic acid. Lipids and other organic materials were revealed by spraying with chromic acid $\left(0.6 \%, \mathrm{w} / \mathrm{w}, \mathrm{Na}_{2} \mathrm{Cr}_{2} \mathrm{O}_{7}\right.$ in $\left.55 \%, \mathrm{w} / \mathrm{w}, \mathrm{H}_{2} \mathrm{SO}_{4}\right)$ and charring at $160{ }^{\circ} \mathrm{C}$ for $\mathrm{I} 5 \mathrm{~min}$. Lipid spots for fatty acid analysis were revealed by spraying with Rhodamine $6 \mathrm{G}(0.5 \%$ in $96 \%$ ethanol) and exposure to u.v. light. Samples (I to $5 \mathrm{mg}$ ) of lipids were chromatographed. Ergosterol, triacylglycerols and free fatty acids were estimated by the colorimetric methods described by Moore \& Baumann (I952), Van Handel \& Zilversmit (I957) and Heinen \& De Vries (I966), respectively.

(iv) Fatty acid analysis. Lipids from t.l.c. plates were transmethylated by the method of Nichols \& Moorhouse (I969). The resulting fatty acid methyl esters were dissolved in small volumes of petroleum spirit (b.p. 40 to $60^{\circ} \mathrm{C}$ ) and analysed by gas-liquid chromatography as described above for neutral-sugar analysis but with the column at $190^{\circ} \mathrm{C}$ throughout. The relative amount of each fatty-acid methyl ester was determined from the peak areas. 

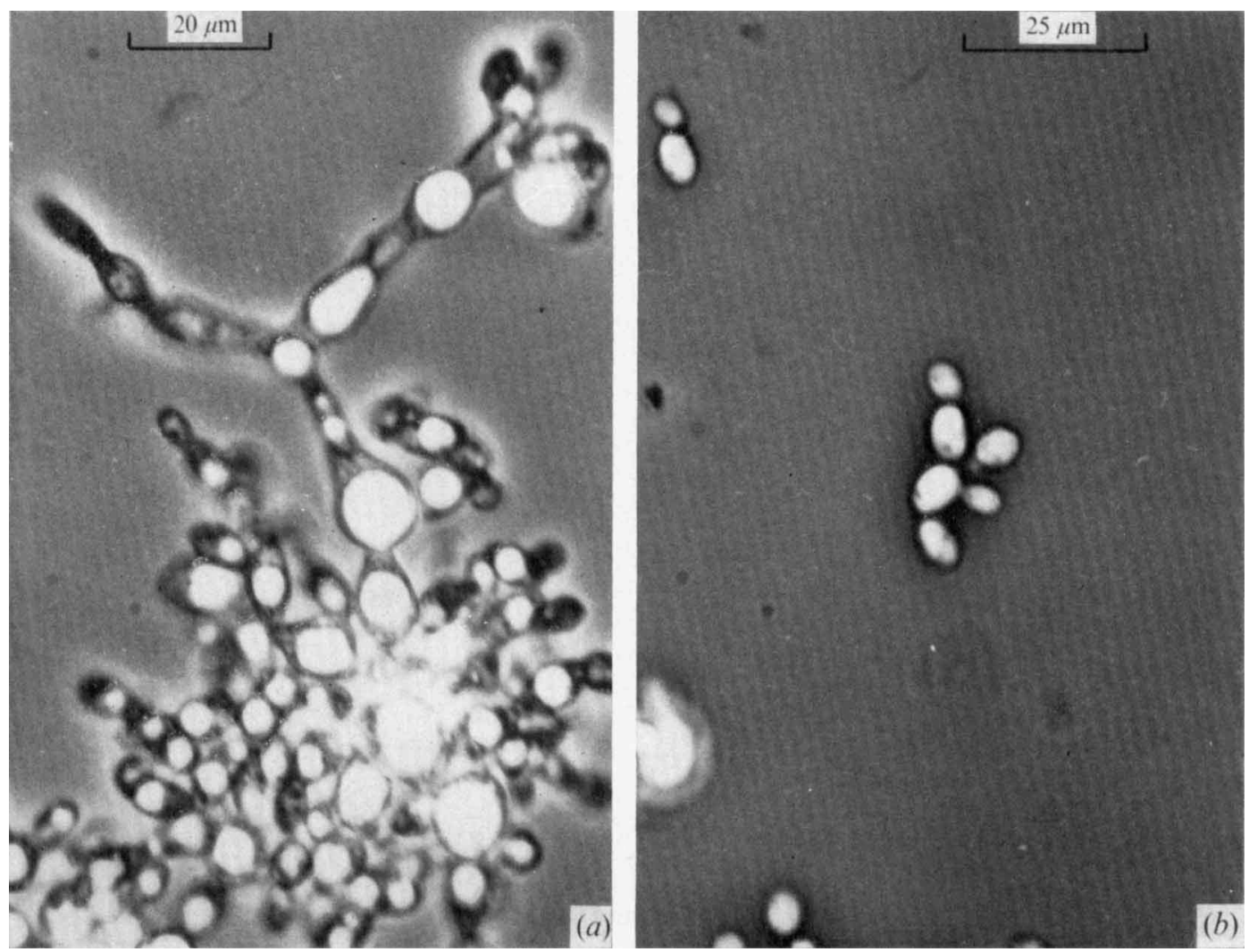

Fig. I. Mutant BI/4 grown in (a) $2 \%$ glucose plus $40 \%$ sucrose, and (b) $2 \%$ glucose plus $60 \%$ sucrose.

\section{RESULTS}

\section{Cell morphology}

The same length (5 to I $5 \mu \mathrm{m}$ ) and ovoid shape of the parent strain of Saccharomyces rouxii was observed at high and low concentrations of sucrose. Mutant B / 4 was unable to grow in defined liquid medium at or below $20 \%$ sucrose. In $30 \%$ sucrose it grew slowly and most of the yeasts were filamentous. When grown in $40 \%$ sucrose a large proportion of the cells were filamentous with large bulbous regions ${ }_{5} 5$ to $20 \mu \mathrm{m}$ in diameter (Fig. I $a$ ). When grown in the presence of $60 \%$ sucrose the cells were morphologically similar to those of the parent strain (Fig. I $b$ ). Sudden reduction in osmotic pressure caused the yeasts to extrude membranous and granular material. Some, but not all, of them became phase-dark on extrusion of intracellular material.

Since glucosamine is a component of yeast cell envelopes (Bacon et al. 1966; Cabib \& Bowers, 197I ; Sentandreau \& Northcote, 1968) it is possible that the observed weakness of mutant BI/4 envelope and the morphological changes are due to an inability to synthesize glucosamine. Supplementing the defined growth medium with $0.1 \%$ glucosamine did not allow growth of mutant $\mathrm{BI} / 4$ in $20 \%$ sucrose. Yeasts grown in medium containing $0.1 \%$ glucosamine, $40 \%$ sucrose and $2 \%$ glucose were unable to adapt to growth in medium containing $0.1 \%$ glucosamine, $20 \%$ sucrose and $2 \%$ glucose. 


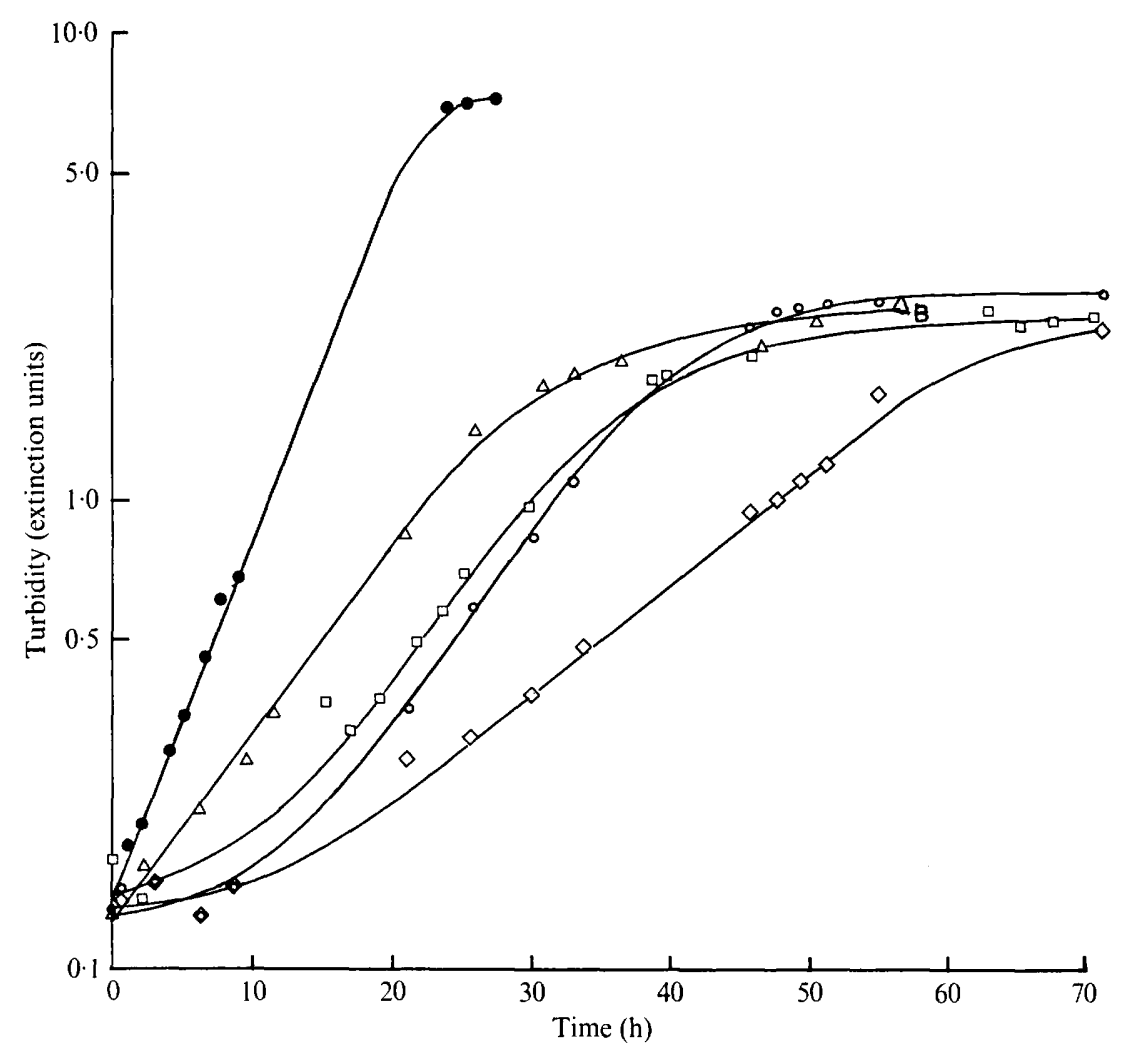

Fig. 2. $\diamond, \triangle, O, \square$, Growth curves of mutant $\mathbf{B I} / 4$ in $\mathrm{D}$ medium plus various concentrations of sugars: $\diamond, 2 \%$ glucose plus $40 \%$ sucrose; $\Delta, 2 \%$ glucose plus $60 \%$ sucrose; $\bigcirc, 10 \%$ glucose plus $40 \%$ sucrose; $\square$, $10 \%$ glucose plus $60 \%$ sucrose. $O$, Growth curve of parent $S$. rouxii in D medium plus $2 \%$ glucose.

\section{Growth characteristics of the parent strain of $S$. rouxii and mutant $\mathrm{BI} / 4$}

The growth curves of both strains in liquid medium containing various solute concentrations are shown in Fig. 2. The parent $S$. rouxii grew to approximately the same turbidity in stationary phase irrespective of the sugar concentration used. Mutant BI/4 also grew to a turbidity that was roughly independent of the sugar concentration and smaller than the final turbidity of the parent strain.

The growth rate of the parent strain of $S$. rouxii was relatively unaffected by changes in the concentrations of glucose, sucrose or $\mathrm{KCl}$, whereas the growth rate of mutant $\mathrm{BI} / 4$ was lower in $2 \%$ glucose plus $40 \%$ sucrose (filamentous form) than in $2 \%$ glucose plus $60 \%$ sucrose (yeast form).

\section{Fragility of the yeasts}

A sudden reduction in osmotic pressure (osmotic shock) resulted in considerable release of protein and u.v.-absorbing material from mutant BI $/ 4$ but a much smaller release from the parent $S$. rouxii (Table I). $\mathrm{KCl}$, isotonic to the growth medium, caused release of some protein and u.v.-absorbing material. Soluble protein released from the mutant constituted 6 to $13 \%$ of the total cell protein as measured by the Lowry-Folin method (Lowry et al. I95I). 
Table I. Release of u.v.-absorbing material from parent $S$. rouxii and mutant $\mathrm{BI} / 4$ on resuspension in isotonic $\mathrm{KCl}$ and in water

Percentages are expressed as \% of total material absorbing at $260 \mathrm{~nm}$ released on bciling the yeast in water for $10 \mathrm{~min}$.

$\begin{array}{lcccc}\text { U.v. absorbing material }(\%) \text { in: } & \overbrace{2 \% \text { Glucose }}^{2 \% \text { Glucose }}+40 \% \text { sucrose } & \begin{array}{c}2 \% \text { Glucose } \\ +40 \% \text { sucrose }+60 \% \text { sucrose }\end{array} \\ 3 \text { washes in } \mathrm{KCl} & \text { I7 } & \text { I4 } & 28 & \text { I3 } \\ 3 \text { washes in } \mathrm{H}_{2} \mathrm{O} & 2 \mathrm{I} & 25 & 72 & 65\end{array}$

Table 2. Percentage composition of parent $S$. rouxii and mutant $\mathrm{BI} / 4$ grown in D medium plus various concentrations of sucrose

Values are expressed as \% cell dry wt; each batch was analysed in triplicate.

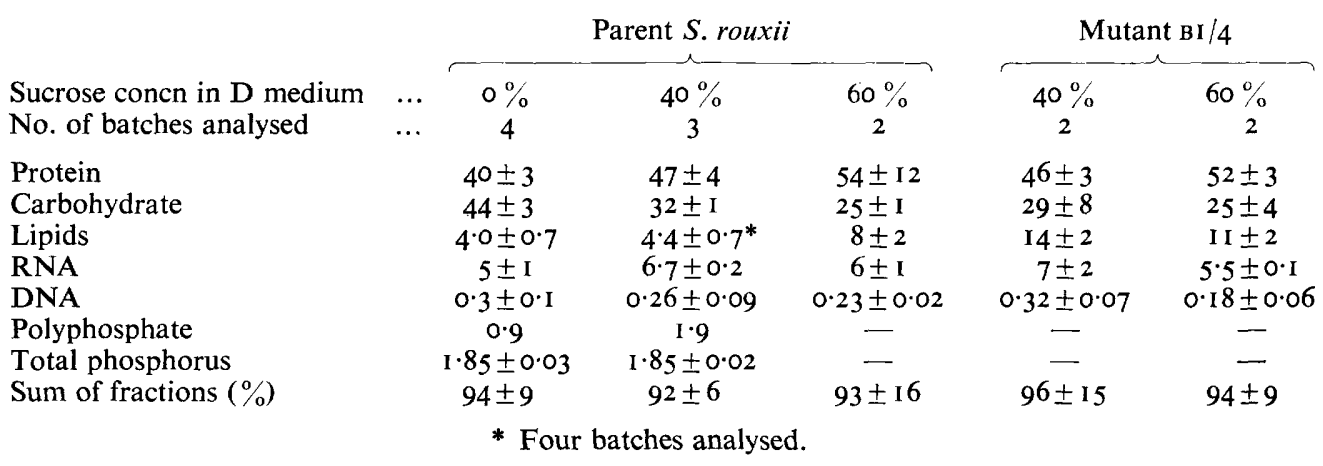

SDH activity of the various fractions recovered during isolation of yeast envelope

Yeast envelope fractions contained less than $2 \%$ of total SDH and hence were presumably free from contamination by mitochondria. Most of the SDH activity was located in the I0000 $\mathrm{g}$ supernatant fractions. The total SDH activity of mutant BI/4 $(0.24$ to $0.42 \mu \mathrm{mol}$ DCPIP reduced $/ \mathrm{min} / \mathrm{mg}$ cells) was significantly lower than that of the parent strain of $S$. rouxii ( $\mathrm{I} \cdot 6$ to $2 \cdot \mathrm{I} \mu \mathrm{mol}$ DCPIP reduced $/ \mathrm{min} / \mathrm{mg}$ cells).

Chemical compositions of whole yeasts and yeast envelopes

Whole yeasts of the parent strain varied in total carbohydrate content, depending on the sucrose concentration of the growth medium (Table 2). The carbohydrate content of yeast grown in high sucrose concentrations was lower than that of yeast grown in the absence of sucrose. This change was accompanied by a corresponding increase in protein and lipid content. Whole cells of mutant BI/4 showed no significant variation in content of these components when grown in media of different sucrose concentrations, and the values were similar to those for the parent strain grown in $60 \%$ sucrose. Neither strain showed significant changes in RNA or DNA content, either between strains or as a result of changes in sucrose concentration in the growth medium.

The envelopes from the parent and the mutant organisms contained similar amounts of total carbohydrate, RNA and DNA. Envelopes from mutant $\mathrm{Br} / 4$ grown in $60 \%$ sucrose had a higher lipid content than envelopes from $40 \%$ sucrose (Table 3 ). Both strains had more protein in the envelope at the higher sucrose concentrations. 
Table 3. Percentage composition of cell envelopes isolated from parent $S$. rouxii and from mutant $\mathrm{BI} / 4$ grown in $D$ medium plus various concentrations of sucrose

Values are expressed as \% dry wt of cell envelope; each batch was analysed in triplicate.

\begin{tabular}{|c|c|c|c|c|}
\hline \multirow{3}{*}{$\begin{array}{l}\text { Sucrose concn in D medium } \\
\text { No. of batches analysed }\end{array}$} & \multicolumn{2}{|c|}{ Parent $S$. rouxii } & \multicolumn{2}{|c|}{ Mutant BI/4 } \\
\hline & $0 \%$ & $40 \%$ & $40 \%$ & $60 \%$ \\
\hline & $\cdots$ & 5 & 5 & 3 \\
\hline \multicolumn{5}{|l|}{$\begin{array}{l}\text { Percentage composition of } \\
\text { envelopes: }\end{array}$} \\
\hline Protein & $8 \pm I$ & $13 \pm 3 \S$ & $10 \pm 2$ & $18 \pm 2$ \\
\hline Glucose: mannose ratio & $I: I$ & I $:$ I & $2: I$ & $1: \mathbf{I}$ \\
\hline Total carbohydrate & $84 \pm 2$ & $78 \pm 5$ & $82 \pm 6$ & $77 \pm 8$ \\
\hline Lipids & $3 \pm I$ & $3.7 \pm 0.8$ & $4 \pm I$ & $9 \pm 2$ \\
\hline RNA & 0.9 & $1 \cdot 4 \pm 0.8$ & $0.9 \pm 0.5$ & $1 \cdot 3 \pm 0.4$ \\
\hline DNA & $<0.006$ & $<0.02$ & $<0.02$ & $<0.06$ \\
\hline Hexosamine & $3.9 \pm 0.4$ & $3.7 \pm 0.3 t$ & $0.8 \pm 0 . I^{*}$ & $0.7 \pm 0.1^{*}$ \\
\hline Total percentage & $100 \pm 5$ & $99 \pm 10$ & $100 \pm 10$ & $106 \pm 13$ \\
\hline \multicolumn{5}{|l|}{$\begin{array}{l}\text { Percentage sugar in total } \\
\text { neutral sugars }\end{array}$} \\
\hline Glucose & $55.5 \pm 0.5$ & $54 \pm 2 \dagger$ & $66 \pm 3 \div$ & $55 \pm \mathrm{I} \dagger$ \\
\hline Mannose & $44.5 \pm 0.5$ & $46 \pm 2 \dagger$ & $34 \pm 3 \ddagger$ & $45 \pm I \dagger$ \\
\hline Glucose:mannose ratio & $1 \cdot 25: 1$ & $I \cdot 17: I$ & I·94:I & $\mathrm{I} \cdot 22: \mathrm{I}$ \\
\hline
\end{tabular}

The envelopes from the parent yeast contained approximately $4 \%$ hexosamine whereas mutant BI/4 contained only $0.8 \%$ (Table 3 ), irrespective of the sucrose concentration.

In both strains, glucose and mannose were the only neutral sugars in the envelopes detected by gas-liquid chromatography. Envelopes of the parent strain had a glucose: mannose ratio of I.2: I (Table 3) when grown either in the absence or presence of $40 \%$ sucrose. When mutant $\mathrm{BI} / 4$ was grown in $40 \%$ sucrose (filamentous form), this ratio was $I \cdot 9: I \cdot 0$, whereas in $60 \%$ sucrose (the yeast form), it was $I \cdot 2: I \cdot 0$, as in the parent strain.

\section{Lipids in whole yeasts and yeast envelopes}

Neutral lipid and phospholipid were the major components of these fractions. Neutral lipid constituted 30 to $70 \%$ and phospholipid 20 to $60 \%$ of the total lipid in whole yeasts of both strains, the proportions being highly variable in different batches. In the envelopes, neutral lipid constituted 55 to $85 \%$ and phospholipid 15 to $45 \%$ of the total lipid. Glycolipid occurred in small amounts $(5 \%)$ and could not be estimated gravimetrically because the redistilled acetone used to elute the material contained non-volatile residues.

\section{The neutral lipid fraction}

Microdensitometry traces of chromic-acid charred thin-layer chromatography plates showed the major fractions to be triacylglycerols, sterol esters and free fatty acids in both whole yeast and yeast envelope lipids. This method of determining relative quantities is subject to considerable error; the intensity of charring varies with degree of cyclization and unsaturation. By colorimetric assay, the neutral lipid from whole yeasts of both strains (I I to I $8 \%$ of the total) was found to contain approximately Io times more ergosterol than that from envelopes $(0.6$ to $2.6 \%$ of the total). Envelope neutral lipid contained more free fatty acids ( 6 to $13 \%$ ) than that from whole yeasts ( 2 to $5 \%$ ) in both strains. Triacylglycerols 
Table 4. Percentage fatty acid content of whole-cell neutral lipids

\begin{tabular}{|c|c|c|c|c|c|c|}
\hline \multirow{2}{*}{$\begin{array}{c}\text { Sucrose concn in D } \\
\text { medium } \quad \ldots \quad \ldots\end{array}$} & \multicolumn{4}{|c|}{ Parent $S$. rouxii } & \multicolumn{2}{|c|}{ Mutant BI $/ 4$} \\
\hline & $0 \% *$ & $0 \% \dagger$ & $40 \% *$ & $60 \% *$ & $40 \% *$ & $60 \% *$ \\
\hline \multicolumn{7}{|l|}{ Fatty acids } \\
\hline $14: 0$ & $\operatorname{Tr}$ & $\operatorname{Tr}$ & $\operatorname{Tr}$ & $2 \cdot I$ & 0.5 & $\operatorname{Tr}$ \\
\hline $15: 1$ & $I \cdot I$ & 0.4 & 0.2 & $0 \cdot 3$ & $\operatorname{Tr}$ & 一 \\
\hline $16: 0$ & $6 \cdot 0$ & $8 \cdot \mathrm{I}$ & $10 \cdot 6$ & $15 \cdot 8$ & $9 \cdot 4$ & $8 \cdot 2$ \\
\hline I6:I & $17 \cdot 4$ & $9 \cdot 9$ & $10 \cdot 6$ & $18 \cdot 3$ & $18 \cdot 2$ & $21 \cdot 4$ \\
\hline $17: 0$ & - & - & $\mathrm{I} \cdot 3$ & - & $3 \cdot I$ & - \\
\hline I 8:0 & $\mathrm{I} \cdot 9$ & $\mathrm{I} \cdot 7$ & $2 \cdot 4$ & $6 \cdot 5$ & $3 \cdot 8$ & $I \cdot 7$ \\
\hline I 8: I & $4 I \cdot 7$ & $47 \cdot 6$ & $27 \cdot 6$ & $47 \cdot 6$ & $31 \cdot 8$ & $45 \cdot 6$ \\
\hline $18: 2$ & $3 I \cdot 0$ & $32 \cdot 7$ & $47 \cdot 3$ & $9 \cdot 4$ & $33 \cdot 3$ & $23 \cdot 2$ \\
\hline $16: 0 / 16: 1$ & 0.35 & 0.82 & $1 \cdot 00$ & 0.86 & 0.52 & 0.38 \\
\hline I $8: 0 / 18: I$ & 0.05 & 0.04 & 0.09 & 0.14 & 0.12 & 0.04 \\
\hline I 8:2/18:I & 0.75 & 0.69 & $\mathrm{I} \cdot 75$ & 0.20 & $I \cdot 05$ & $0.5 \mathrm{I}$ \\
\hline \multirow{2}{*}{$\begin{array}{l}\text { Unsaturated fatty acids } \\
(\% \text { of total })\end{array}$} & $9 \mathrm{I} \cdot 2$ & $90 \cdot 6$ & $85 \cdot 7$ & $75 \cdot 6$ & $83 \cdot 3$ & $90 \cdot 2$ \\
\hline & \multicolumn{6}{|c|}{$\begin{array}{l}\text { Tr, trace amounts present }(<0.2 \%) \\
* \text { Mid- exponential phase of growth. } \\
\dagger \text { Late exponential phase of growth. }\end{array}$} \\
\hline
\end{tabular}

Table 5. Percentage fatty acid content of whole-cell sterol esters from organisms grown in $D$ medium plus various concentrations of sucrose

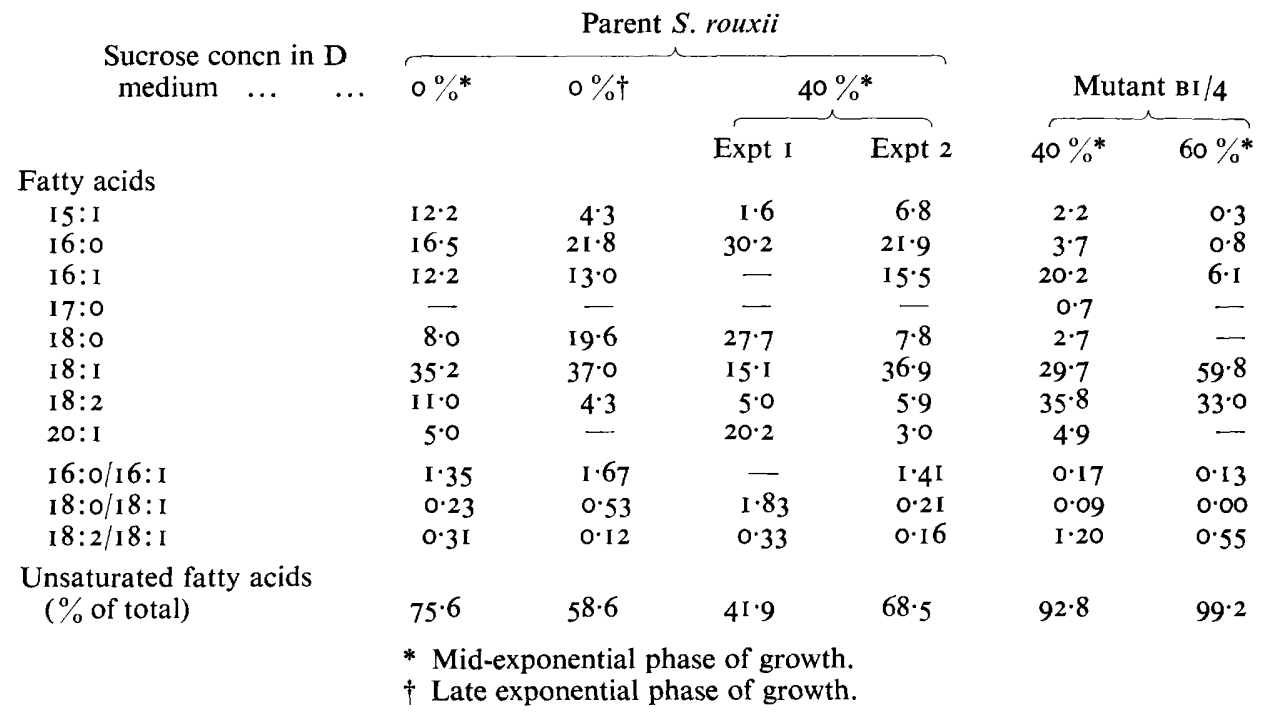

constituted by far the largest fraction of the neutral lipids ( 80 to $90 \%$ ) in both the whole cell and the cell envelopes of both strains.

Fatty acids in neutral lipid esters. In the parent strain of $S$. rouxii and in the mutant $\mathrm{BI} / 4$ the major fatty acid components of all the neutral lipid fractions were the unsaturated $C_{16: 1}, C_{18: 1}$ and $C_{18: 2}$. Both strains contained relatively little $C_{18: 0}$ fatty acid (Table 4 ). The $\mathrm{C}_{16: 0}$ to $\mathrm{C}_{16: 1}$ ratio for whole-cell neutral lipid from mutant $\mathrm{BI} / 4$ was lower than that for the parent yeast grown in defined medium containing $2 \%$ glucose and 40 or $60 \%$ sucrose. Both strains had higher ratios in $40 \%$ than in $60 \%$ sucrose. When the parent strain was grown in $2 \%$ glucose alone, the ratio was similar to that of the mutant. 
Table 6. Ratios of fatty acids in various neutral lipid fractions of whole cells and envelopes of the parent yeast and its mutant $\mathrm{BI} / 4$ grown in D medium plus various concentrations of sucrose

The numbers of batches analysed are given in parentheses.

\begin{tabular}{|c|c|c|c|c|c|c|c|}
\hline \multirow[b]{2}{*}{ Lipid } & \multirow{2}{*}{$\begin{array}{c}\text { Sucrose } \\
\text { concn } \\
(\%)\end{array}$} & \multicolumn{3}{|c|}{ Parent $S$. rouxii } & \multicolumn{3}{|c|}{ Mutant BI/4 } \\
\hline & & $16: 0 / 16: I$ & I8:0/18:I & I $8: 2 / 18: I$ & $16: 0 / 16: I$ & 18:0/I 8: I & I $8: 2 / 18: \mathrm{I}$ \\
\hline $\begin{array}{l}\text { Cell-envelope sterol } \\
\text { esters }\end{array}$ & $\begin{array}{l}40 \\
60\end{array}$ & $\begin{array}{c}0.32 \pm 0.03 \\
(2) \\
-\end{array}$ & $\begin{array}{c}0.10 \pm 0.06 \\
(2) \\
-\end{array}$ & $\begin{array}{c}0.3 \pm 0.2 \\
(2) \\
\cdots\end{array}$ & $\begin{array}{c}0.29 \pm 0.07 \\
(3) \\
0.09 \pm 0.02 \\
(2)\end{array}$ & $\begin{array}{c}0.07 \pm 0.02 \\
(3) \\
0.02 \pm 0.01 \\
(2)\end{array}$ & $\begin{array}{c}0.08 \pm 0.02 \\
(3) \\
0\end{array}$ \\
\hline $\begin{array}{l}\text { Whole-cell triacyl- } \\
\text { glycerol }\end{array}$ & 0 & $0.6 \pm 0.3$ & $0.06 \pm 0.01$ & $0.74 \pm 0.02$ & - & - & - \\
\hline & $\begin{array}{l}40 \\
60\end{array}$ & $\begin{array}{l}I \cdot 65 \\
I \cdot 32\end{array}$ & $\begin{array}{l}0.11 \\
0.10\end{array}$ & $\begin{array}{l}0.83 \\
0.3 \mathrm{I}\end{array}$ & $\begin{array}{l}0.47 \\
0.47\end{array}$ & $\begin{array}{l}0.04 \\
0.09\end{array}$ & $\begin{array}{l}0.97 \\
0.50\end{array}$ \\
\hline $\begin{array}{l}\text { Cell-envelope triacyl- } \\
\text { glycerol }\end{array}$ & $\begin{array}{l}40 \\
60\end{array}$ & $\begin{array}{c}I \cdot 3 \pm 0 \cdot 4 \\
(3) \\
-\end{array}$ & $\begin{array}{c}0.2 \pm 0 \cdot I \\
(3) \\
-\end{array}$ & $\begin{array}{c}0.4 \pm 0.2 \\
(3) \\
-\end{array}$ & $\begin{array}{c}0.9 \pm 0.2 \\
(3) \\
0.81 \pm 0.04 \\
(2)\end{array}$ & $\begin{array}{c}0.08 \pm 0.04 \\
(3) \\
0.06 \pm 0.01 \\
(2)\end{array}$ & $\begin{array}{c}0.24 \pm 0.08 \\
(3) \\
0.28 \pm 0.02 \\
(2)\end{array}$ \\
\hline $\begin{array}{l}\text { Whole-cell free fatty } \\
\text { acids }\end{array}$ & $\begin{array}{l}40 \\
60\end{array}$ & $\begin{array}{c}2 \cdot 18 \\
-\end{array}$ & 0.15 & 0.97 & $\begin{array}{l}3 \cdot 26 \\
2 \cdot 98\end{array}$ & $\begin{array}{l}0.21 \\
0.05\end{array}$ & $\begin{array}{l}0.41 \\
0.18\end{array}$ \\
\hline $\begin{array}{l}\text { Cell-envelope free } \\
\text { fatty acids }\end{array}$ & $\begin{array}{l}40 \\
60\end{array}$ & $\begin{array}{c}5 \pm 2 \\
(2) \\
-\end{array}$ & $\begin{array}{c}0.22 \\
(2) \\
-\end{array}$ & $\begin{array}{c}0.1 \mathrm{I} \pm 0.04 \\
(2) \\
-\end{array}$ & $\begin{array}{c}\mathrm{I} \cdot 5 \pm 0.8 \\
(3) \\
\mathrm{I} \cdot 52 \pm 0.01 \\
(2)\end{array}$ & $\begin{array}{c}0.17 \pm 0.04 \\
(3) \\
0.10 \pm 0.01 \\
(2)\end{array}$ & $\begin{array}{c}0.14 \pm 0.02 \\
(3) \\
0.15 \pm 0.04 \\
(3)\end{array}$ \\
\hline
\end{tabular}

Sterol esters from whole cells showed a great difference in $\mathrm{C}_{16: 0}$ to $\mathrm{C}_{16: 1}$ ratio between the parent and the mutant $\mathrm{BI} / 4$, and a smaller but significant variation with respect to the ratios $C_{18: 0}$ to $C_{18: 1}$ and $C_{18: 2}$ to $C_{18: 1}$ (Table 5). Mutant whole-cell sterol esters contained less $C_{16: 0}$ and $C_{18: 0}$ but more $C_{18: 2}$ fatty acids. These variations were not observed in the cell envelope sterol esters which generally contained much less $\mathrm{C}_{18: 2}$ fatty acid.

The triacylglycerol fraction of whole-cell lipids from the mutant had lower $C_{16: 0}$ to $C_{16: 1}$ ratios and slightly higher $C_{18: 2}$ to $C_{18: 1}$ ratios than the corresponding fractions from the parent yeast grown in similar media (Table 6). Omitting sucrose lowered the $\mathrm{C}_{16: 0}$ to $\mathrm{C}_{16: 1}$ ratio for the parent strain, mainly because the $\mathrm{C}_{16: 0}$ content fell. There was no meaningful change in the $\mathrm{C}_{18: 0}$ to $\mathrm{C}_{18: 1}$ ratio between the strains. The $\mathrm{C}_{18: 2}$ to $\mathrm{C}_{18: 1}$ ratio decreased when both strains were grown in $60 \%$ sucrose as compared with $40 \%$.

For cell-envelope triacylglycerol, the $\mathrm{C}_{16: 0}$ to $\mathrm{C}_{16: 1}$ ratio for mutant $\mathrm{BI} / 4$ was approximately $65 \%$ that of the parent strain (Table 6). The $\mathrm{C}_{18: 0}$ to $\mathrm{C}_{18: 1}$ ratio was also generally lower for mutant $\mathrm{BI} / 4$, while the $\mathrm{C}_{18: 2}$ to $\mathrm{C}_{18: 1}$ ratio showed no significant variation. For whole yeasts and cell envelopes percentages of $\mathrm{C}_{16: 0}, \mathrm{C}_{16: 1}, \mathrm{C}_{18: 0}$ and $\mathrm{C}_{18: 1}$ fatty acids in triacylglycerol were similar in both strains. There was a decrease in the percentages of $C_{18: 2}$ fatty acid in the envelope triacylglycerol compared with whole-cell triacylglycerol.

There is a general tendency for the $C_{16: 0}$ to $C_{16: 1}$ and $C_{18: 0}$ to $C_{18: 1}$ ratios to be lower in mutant BI $/ 4$ neutral lipids than in parent strain neutral lipids, from both whole cells and cell envelopes. Also there is a general tendency for neutral lipids from mutant BI $/ 4$ to have a higher content of unsaturated fatty acids than do the lipids from the parent strain.

Free fatty acids in the neutral lipid fraction. Whole-cell free fatty acids of mutant $\mathrm{BI} / 4$ showed higher $C_{16: 0}$ to $C_{16: 1}$ ratios than did the parent strain, whereas the $C_{18: 2}$ to $C_{18: 1}$ ratios were lower for the mutant (Table 6 ). The free fatty acids of mutant $\mathrm{BI} / 4$ cell envelope had lower $C_{16: 0}$ to $C_{16: 1}$ and $C_{18: 0}$ to $C_{18: 1}$ ratios than those of the parent strain, mainly due 
to a decrease in $C_{16: 0}$ and $C_{18: 0}$ content. Both strains had a similar $C_{18: 2}$ to $C_{18: 1}$ ratio in the envelope free fatty acids. The $\mathrm{C}_{18: 2}$ fatty acid was relatively constant in both strains. The difference in $\mathrm{C}_{18: 0}$ to $\mathrm{C}_{18: 1}$ ratios is very slight but the trend is again towards lower ratios for mutant BI $/ 4$.

\section{Fatty acids of the phospholipid fraction}

Phospholipid was fractionated into cardiolipin, phosphatidyl ethanolamine, phosphatidyl choline plus phosphatidyl serine, and phosphatidyl inositol by thin-layer chromatography as described. The fatty acids from each fraction were subjected to gas-liquid chromatography which showed the major fatty acids in both parent and mutant BI/4 to be $\mathrm{C}_{16: 0}, \mathrm{C}_{18: 0}$, and $\mathrm{C}_{18: 1}$. There were no obvious differences between the two strains in the ratios $C_{16: 0}$ to $C_{16: 1}, C_{18: 6}$ to $C_{18: 1}$ and $C_{18: 2}$ to $C_{18: 1}$.

\section{DISCUSSION}

The fragility of mutant BI/4 when suspended in media of low osmotic pressure, its filamentous form in $40 \%$ sucrose and the low hexosamine content of the envelope (Table 3) suggest that the mutation(s) may affect the synthesis of envelope components and of bud scars which are centres of chitin accumulation (Bacon et al. I966; Cabib \& Bowers, I97I). The growth rate in medium supplemented with $40 \%$ sucrose (filamentous form) was approximately $50 \%$ of that in $60 \%$ sucrose (yeast form), or $10 \%$ glucose plus $60 \%$ sucrose (Fig. 2 ). This variation in growth rate with solute concentration was not observed with the parent strain; this suggests that at low external osmotic pressures the functions of the cytoplasmic membrane were impaired, which resulted in an impaired uptake of nutrients, a leakage of low molecular weight substances from the cell pool, or impaired wall synthesis. Since the yeast suspended in isotonic $\mathrm{KCl}$ did not leak more material than did the parent strain (Table I), leakage of low molecular weight material from the cell pool is unlikely to have caused the variation in growth rate. It is apparent that one cause (and possibly the most important one) of obligate osmophilism in mutant $\mathrm{BI} / 4$ is the inability of the yeast to synthesize a wall capable of protecting the plasma membrane in environments of low osmotic pressure.

The chemical composition of whole yeasts (Table 2) showed that growth of the parent strain of $S$. rouxii in high sucrose concentrations led to a reduction in the total carbohydrate content. This could be due to a decrease in accumulation of storage carbohydrates, caused by an increase in fermentation rate. Sucrose would not be directly involved in this phenomenon, since the cells are impermeable to this sugar and lack surface invertase (Scarr, I95I).

The chemical compositions of the envelopes of both the parent and the BI/4 strains were similar. These results are, with some exceptions, in general agreement with those reported for S. cerevisiae by Falcone \& Nickerson (1956), Eddy (1958) and Northcote \& Horne (1952). The hexosamine content found for $S$. rouxii (approx. $4 \%$ ) is 1.5 to 2.0 times that found by Falcone \& Nickerson (1956), Eddy (1958) and Northcote \& Horne (1952) for $S$. cerevisiae. Estimates of carbohydrate content are in general agreement with those of Falcone \& Nickerson (I956) but higher than those of Northcote \& Horne (I952).

The most interesting changes in the cell envelope, due to mutation, were:

(i) A decrease in hexosamine content. This is at variance with the findings of BartnickiGarcia \& Nickerson (1962) and Chattaway, Holmes \& Barlow (1968) on the filamentous and yeast forms of Mucor rouxii and Candida albicans respectively. These authors found that the hexosamine contents of the walls of the filamentous forms of their organisms were 
greater than those of the yeast forms. Chattaway et al. (1968) showed that this hexosamine was mainly chitin. However, Kobayashi \& Guiliacci (1967) found that the wall from the yeast form of Histoplasma capsulatum contained more hexosamine than the wall of the filamentous form.

Most of the hexosamine of $S$. rouxii envelopes is probably a component of mannanprotein complexes, similar to those isolated by Kessler \& Nickerson (I959) and Korn \& Northcote (1960) from S. cerevisiae, where the hexosamine serves as a link between the mannan and the protein moieties of the macromolecule (Sentandreau \& Northcote, 1968). These complexes may confer mechanical strength on the envelope of the parent strain of $S$. rouxii. In mutant $\mathrm{BI} / 4$, the low hexosamine content of the cell envelope and the extrusion of intracellular material in environments of low osmotic pressure suggest that the mutant may be unable to synthesize, or assemble, components of these mannan-protein complexes.

(ii) The variation in the ratio of glucose to mannose when the yeast was grown in various sucrose concentrations. This ratio $(1 \cdot 2: 1 \cdot 0)$ for the envelopes was the same for $S$. rouxii grown in $2 \%$ glucose or in $2 \%$ glucose plus $40 \%$ sucrose and for the mutant grown with $60 \%$ sucrose. The value is similar to that reported by Northcote \& Horne (1952) for $S$. cerevisiae. After growth in $2 \%$ glucose plus $40 \%$ sucrose (filamentous form), the glucose to mannose ratio for the mutant cell envelopes was $\mathrm{I} \cdot 9: \mathrm{I} \cdot 0$. This suggests that there had been a loss of some mannose component ( $25 \%$ of total neutral sugars), an increase in the glucose component, or a combination of both factors. Since one of the outer layers of the yeast envelope may be composed of mannans (Northcote, 1963) or mannan-protein complexes, it is possible that this layer is not synthesized when the mutant is grown under these conditions. Alternatively, this layer could be synthesized but fail to be incorporated in the envelope in the absence of sufficient hexosamine, and hence be secreted into the growth medium.

The difference in hexosamine content between the mutant B $/ 4$ envelope and that of the parent strain could not have resulted from differences in growth rate, because the envelope of the mutant BI/4 grown in the presence of 40 or $60 \%$ sucrose had the same hexosamine content although the growth rates $\left(0.078\right.$ and $0.127 \mathrm{~h}^{-1}$, respectively) were different. Similarly, the elevated glucose:mannose ratio for mutant BI/4 grown in the presence of $40 \%$ sucrose $(I \cdot 9: I \cdot 0)$ was not solely due to a reduction in growth rate; the glucose: mannose ratio for the mutant grown in $60 \%$ sucrose was the same $(1 \cdot 2: 1 \cdot 0)$ as that for the parent strain, whether the latter was grown without sucrose or in $40 \%$ sucrose, although there were significant differences in the growth rates of these two strains.

(iii) Changes in lipid composition. Neutral lipids were a major component of this fraction in both whole cells and cell envelopes. Triacylglycerol was the major component of neutral lipids - in agreement with the findings of Hunter \& Rose (I972) and Suomalainen \& Nurminen (1970) for $S$. cerevisiae. These triacylglycerols appear to be major components either of the yeast plasma membrane or, at least, of that part of the envelope external to this membrane. The occurrence of free fatty acids in the lipids of envelopes has been suggested by Eddy (1958), and Hunter \& Rose (1972) found that about $10 \%$ of whole-cell neutral lipids was present as free fatty acids.

The fatty acid compositions of neutral lipids showed that the major fatty acids were $\mathrm{C}_{16: 0}, \mathrm{C}_{16: 1}, \mathrm{C}_{18: 1}$ and $\mathrm{C}_{18: 2}$, and it is possible that changes in the ratios of these fatty acids might cause changes in the properties of the cell membranes. That the properties of the cell membrane depend on the nature of its fatty acid content has been reported by Proudlock, Haslam \& Linnane (1969) for yeast mitochondrial oxidative phosphorylation, by Schairer \& Overath (1969) for thiomethyl galactoside transport in an Escherichia coli mutant auxo- 
trophic for oleic acid, and by Garland \& Cori (1972) for rat-liver microsomal glucose-6phosphatase activity. The present study showed that the $C_{16: 0}$ to $C_{16: 1}$ ratios for neutral lipids, sterol esters and triacylglycerols of whole yeasts, and for triacylglycerols and free fatty acids of envelopes were lower for mutant BI $/ 4$ than for the parent, $S$. rouxii, when this was grown in high sucrose concentrations. Generally there was a greater content of unsaturated fatty acids in lipids from mutant yeasts and their envelopes. Increase in content of unsaturated fatty acids in lipids from the mutant could result in an increase in fluidity of the cell membranes. Changes in force-area diagrams indicate that there is an increase in fluidity of artificial membranes caused by an increase in the content of unsaturated fatty acids (Demel, Van Deenen \& Pethica, 1967). In mutant BI/4, this increase in membrane fluidity could have resulted in the structural and enzymic changes reflected in the following observations: ease of lysis; reduction in succinic dehydrogenase activity; changes in the glucose/mannose ratio of the envelope; filamentous growth in $40 \%$ sucrose.

The author is grateful to the Wellcome Foundation for a research studentship, Dr R. Davies who supervised the work, and members of this sub-department for much useful discussion and encouragement.

\section{REFERENCES}

Bacon, J. S., Davidson, E. D., Jones, D. \& TAYlor, I. F. (1966). The location of chitin in yeast cell wall. Biochemical Journal roI, $36 \mathrm{C}-38 \mathrm{C}$.

BARTNICKI-GARCIA, S. \& Nickerson, W. J. (1962). Isolation, composition, and structure of cell walls of filamentous and yeast-like forms of Mucor rouxii. Biochimica et biophysica acta 58, 102-I 19.

BURTON, K. (1956). A study of the conditions and mechanism of the diphenylamine reaction for the colorimetric estimation of deoxyribonucleic acid. Biochemical Journal 62, 315-323.

CABIB, E. \& BowERs, B. (I97I). Chitin and yeast budding - localisation of chitin in yeast bud scars. Journal of Biological Chemistry 246, I 52-159.

Chattaway, F. W., Holmes, M. R. \& Barlow, A. J. E. (1968). Cell wall composition of the mycelial and blastospore forms of Candida albicans. Journal of General Microbiology 51, 367-376.

Davies, R. (1964). Lactose utilization and hydrolysis in Saccharomyces fragilis. Journal of General Microbiology 37, 8I-98.

Demel, R. A., Van Deenen, L. L. M. \& Pethica, B. A. (I967). Monolayer interactions of phospholipids and cholesterol. Biochimica et biophysica acta 135, I I-I9.

Devor, A. W. (1950). Carbohydrate tests using sulphonated $\alpha$-naphthol. Journal of the American Chemical Society 72, 2008-20I2.

DitTMER, J. C. \& LeSTER, R. L. (1964). A simple, specific spray for the detection of phospholipids on thinlayer chromatograms. Journal of Lipid Research 5, 126-127.

DunCAN, H. M. \& MACKLER, B. (1966). Electron transport systems of yeast. III. Preparation and properties of cytochrome oxidase. Journal of Biological Chemistry 24I, 1694-1 697.

EdDy, A. A. (1958). The structure of the yeast cell wall. II. Degradative studies with enzymes. Proceedings of the Royal Society B 149, 425-440.

FALCONE, G. \& Nickerson, W. J. (1956). Cell-wall mannan-protein of baker's yeast. Science, New York 124, $272-273$.

Garland, R. C. \& CoRI, C. F. (1972). Separation of phospholipids from glucose-6-phosphatase by gelchromatography. Specificity of phospholipid reactivation. Biochemistry II, 4712-4718.

GhuYsen, J. M., Tipper, D. J. \& Strominger, J. L. (1966). Enzymes that degrade bacterial cell walls. In Methods in Enzymology, vol. 8, pp. 685-699.

Giles, K. W. \& MYer, A. (1965). An improved diphenylamine method for the estimation of deoxyribonucleic acid. Nature, London 206, 93.

Heinen, W. \& De Vries, H. (I966). A combined micro and semi-micro colorimetric determination of longchain fatty acids from plant cutin. Archiv für Mikrobiologie 54, 339-349.

HUNTER, K. \& ROSE, A. H. (1972). Lipid composition of Saccharomyces cerevisiae as influenced by growth temperature. Biochimica et biophysica acta 260, 639-653. 
KesSLER, G. \& NICKERSON, W. J. (1959). Glucomannan-protein complexes from cell walls of yeasts. Journal of Biological Chemistry 234, 228I-2285.

KoH, T. Y. (1975). The isolation of obligate osmophilic mutants of the yeast Saccharomyces rouxii. Journal of General Microbiology 88, I84-I 88.

KobaYAshi, G. S. \& GuiliacCI, P. L. (1967). Cell wall studies of Histoplasma capsulatum. Sabouraudia 5, I $80-188$.

Korn, E. D. \& Northcote, D. H. (1960). Physical and chemical properties of polysaccharides and glycoproteins of the yeast-cell wall. Biochemical Journal 75, I2-17.

Lowry, O. H., Rosebrough, N. J., Farr, A. L. \& Randall, R. J. (195 I). Protein measurement with the Folin phenol reagent. Journal of Biological Chemistry 193, 265-275.

MoORE, P. R. \& BAUMANN, C. A. (1952). Skin sterols. I. Colorimetric determination of cholesterol and other sterols in skin. Journal of Biological Chemistry 195, 6I 5-62I.

Nichols, B. W. \& MoorhouSE, R. (1969). The separation, structure and metabolism of monogalactosyl diglyceride species in Chlorella vulgaris. Lipids 4, 31 I-316.

NorthCote, D. H. (1963). The nature of plant cell surfaces. Biochemical Society Symposia 22, I05-I 25.

NorthCOTE, D. H. \& HoRne, R. W. (1952). The chemical composition and structure of the yeast cell wall. Biochemical Journal 5I, 232-236.

Nurminen, T., Oura, E. \& Suomalainen, H. (1970). The enzymic composition of the isolated cell wall and plasma membrane of baker's yeast. Biochemical Journal 116, 6I-69.

Proudlock, J. W., Haslam, J. M. \& Linnane, A. W. (1969). Specific effect of unsaturated fatty acid depletion on mitochondrial oxidative phosphorylation in Saccharomyces cerevisiae. Biochemical and Biophysical Research Communications 37, 847-852.

Rouser, G., KRITCHEVSKY, G. \& YAMAmoto, A. (1967). Column chromatographic and associated procedures for separation and determination of phosphatides and glycolipids. In Lipid Chromatographic Analysis, vol. I, pp. 99-162. Edited by G. V. Marinetti. London: Edward Arnold.

Saeman, J. F., Moore, W. E., Mitchell, R. L. \& Millett, A. A. (1954). Techniques for the determination of pulp constituents by quantitative paper chromatography. Technical Association Papers. Technical Association of the Pulp and Paper Industry 37, 336-343.

SCARR, M. P. (195I). Osmophilic yeasts in raw beet and cane sugars and intermediate sugar-refining products. Journal of General Microbiology 5, 704-713.

SCARR, M. P. \& Rose, D. (1966). Study of osmophilic yeasts producing invertase. Journal of General Microbiology 45, 9-16.

SCHAIRER, H. V. \& OVERATH, P. (I969). Lipids containing trans-unsaturated fatty acids change the temperature characteristic of thiomethylgalactoside accumulation in Escherichia coli. Journal of Molecular Biology 44, 209-2I4.

Sentandreau, R. \& NorthCote, D. H. (1968). The structure of a glycopeptide isolated from the yeast cell wall. Biochemical Journal 109, 419-432.

Suomalainen, H. \& Nurminen, T. (1970). The lipid composition of cell wall and plasma membrane of baker's yeast. Chemistry and Physics of Lipids 4, 247-256.

Sweeley, C. C., Bentley, R., Makita, M. \& Wells, W. W. (1963). Gas-liquid chromatography of trimethylsilyl derivatives of sugars and related substances. Journal of the American Chemical Society 85, 2497-2507.

VAN HANDel, E. \& Zilversmit, D. B. (1957). Micromethod for the direct determination of serum triglycerides. Journal of Laboratory and Clinical Medicine 50, 152-157.

Wells, M. A. \& Ditrmer, J. C. (1963). The use of Sephadex for the removal of nonlipid contaminants from lipid extracts. Biochemistry 2, I259-1263. 